\title{
The synthesis of polymers of intrinsic microporosity (PIMs)
}

\author{
Neil B. McKeown* \\ School of Chemistry, University of Edinburgh, David Brewster Road, Edinburgh, EH9 3FJ, UK
}

Received March 10, 2017; accepted April 13, 2017; published online July 4, 2017

\begin{abstract}
Polymers of intrinsic microporosity (PIMs) are a class of porous organic polymer (POP) that form microporous solids due to the inefficient packing of their rigid and contorted macromolecular chains. In contrast to other types of POP, PIMs are not comprised of a network of cross-linked covalent bonds so that they can be dissolved in organic solvents and processed into robust films, coatings or fibres. Here, over twelve years' accumulated research on the synthesis of PIMs is reviewed. To date, three types of polymerisation reaction have been used successfully to prepare PIMs of sufficient molecular mass to form robust self-standing films. These involve the formation of dibenzodioxin, Tröger's base and imide linkages between monomeric units. This rapid development of synthetic methods for preparing PIMs has been driven by their rich potential for numerous diverse applications and this synergistic relationship between synthesis and functionality is set to continue.
\end{abstract}

polymers of intrinsic microporosity, synthesis, porous organic polymers

Citation: McKeown NB. The synthesis of polymers of intrinsic microporosity (PIMs) . Sci China Chem, 2017, 60: 1023-1032, doi: 10.1007/s11426-017-9058-x

\section{Introduction}

The microporous materials contain free volume consisting of interconnected pores of diameter less than $2.0 \mathrm{~nm}$. Over recent years there has been increasing interest in the preparation of new microporous materials using organic components [1]. For example, there are numerous different types of porous organic polymers (POPs) including structurally ordered covalent-organic-frameworks (COFs) and amorphous network polymers such as hypercrosslinked polymers (HCPs), microporous conjugated polymers (MCPs) and porous aromatic frameworks (PAFs). Polymers of intrinsic microporosity (PIMs) generate porosity from their rigid and contorted macromolecular chains that do not pack efficiently in the solid state [2-5]. PIMs differ from other types of POPs in that they do not possess a network structure and, hence, are often freely soluble in organic solvents. The solubility

*Corresponding author (email: neil.mckeown@ed.ac.uk) of PIMs allows them to be processed into self-standing films and coatings and, therefore, they are suitable for making devices such as sensors [6,7] or for the fabrication of polymer membranes [8], particularly for gas separations [9] but also for electrochemical applications [10,11]. To date, around 300 papers have been published dealing directly with the synthesis, modeling, physical properties and applications of PIMs. In addition, there have also been numerous patent applications related to the preparation of PIMs or for inventions for which they play a crucial role. Notably, an end-of-life-service-indicator for 3M's disposable respirator cartridge for organic vapours became the first commercial application of PIMs in 2015 [7]. Here we focus on the research relating to the synthesis of PIMs and review the literature up to the end of 2016.

\section{How to design a PIM}

As noted above the design concept of PIMs requires that the non-network macromolecular structure is both rigid and con- 
torted (i.e. non-linear). To maintain permanent microporosity, it is also crucial to ensure that rotation along the polymer chain is prohibited via a fused ring structure, or strongly hindered by steric inhibition to rotation, to avoid conformation changes that would help the polymer to pack more efficiently. This dictates the use of both conformationally locked monomers and a polymerisation reaction that provides a linkage about which rotation is either prohibited (e.g. a fused ring) or severely restricted via steric hindrance. The sites of contortion necessary to avoid a linear structure can be provided by the monomer (e.g. the spiro-centres of PIM-1), the linking group (e.g. Tröger's base), or both. In principle many step-growth polymerisation reactions could be used to prepare PIMs but in practise only a few are of proven utility for the preparation of solution processable materials, such as cast films, and these are based on forming dibenzodioxin, Tröger's base and imide linkages. PIMs derived from these three types of reactions are described below and specific information and references provided in the accompanying tables. However, other polymerisation reactions show promise including cross-coupling reactions to make conjugated PIMs (C-PIMs) [12,13], triazine formation [14], palladium-catalysed annulation [15] and stepwise nucleophilic substitution of octafluorocyclopentene [16]. In addition, interfacial polymerisation using simple ester or amide linkages but using suitable monomers to induce intrinsic microporosity is a promising technique for making ultra-thin membranes [17].

\section{PIM polymerisation using dibenzodioxane formation}

The first successful polymerization reaction to produce a soluble PIM involved the aromatic nucleophilic substitution $\left(\mathrm{S}_{\mathrm{N}} \mathrm{Ar}\right)$ mechanism between a biscatechol (A, Scheme 1) and a tetrahalide-containing monomer (B, Scheme 1) to form dibenzodioxin-linked polymers (Table 1). This reaction was initially used to prepare microporous network polymers [18-20] but was subsequently found to be capable of forming a fused-ring linking group with sufficient efficiency to provide solution processable ladder polymers of high average molecular mass [2,8,21]. Generally, aromatic nucleophilic substitutions require the halide-containing monomer to be activated by an electron-withdrawing substituent (e.g. $-\mathrm{CN}, \mathrm{F}$ ) [22]. For example PIM-1, the archetypal PIM, is readily prepared by the reaction between the commercially available monomers 5,5'6,6'-tetrahydroxy-3,3,3',3'-tetramethyl-1,1'-spirobisindane (A1) and 2,3,5,6-tetrafluoroterephthalonitrile (B1) [2,8]. The original method of making PIM-1 (sometimes called the "low temperature method") involves mixing the two monomers in equimolar quantity in a solution of anhydrous dimethyl formamide (DMF) with a two-fold
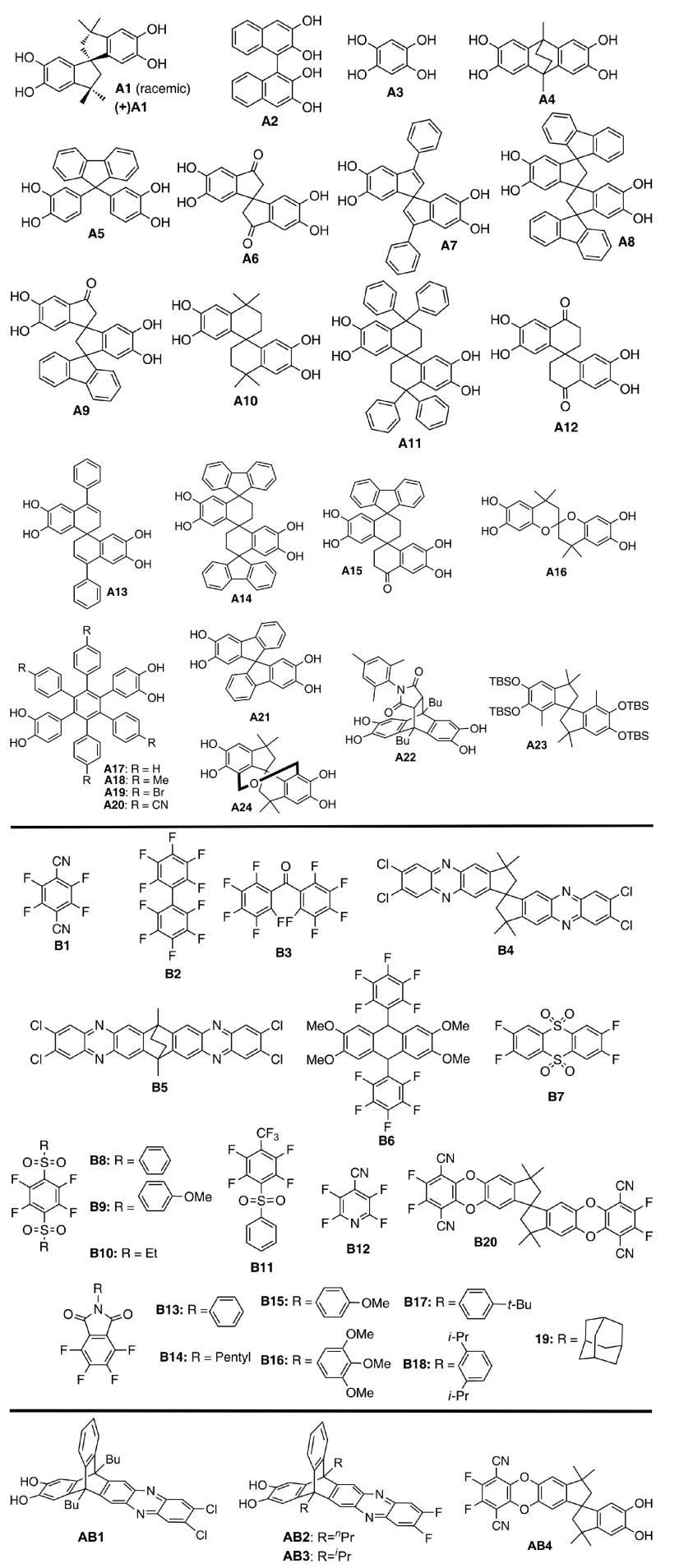

Scheme 1 Structures of monomers A1-A24, B1-B20 and AB1-AB4.

excess of finely powdered dry potassium carbonate at $50-60^{\circ} \mathrm{C}$ for $24-72 \mathrm{~h}$. This relatively low temperature avoids the decomposition of DMF to dimethylamine, which is a sufficiently strong nucleophile to interfere with the reaction. The concentration of monomers is critical as at very high concentrations insoluble cross-linked material is produced whereas at low concentrations a large amount of cyclic olig- 
Table 1 PIMs prepared via dibenzodioxane polymerisation
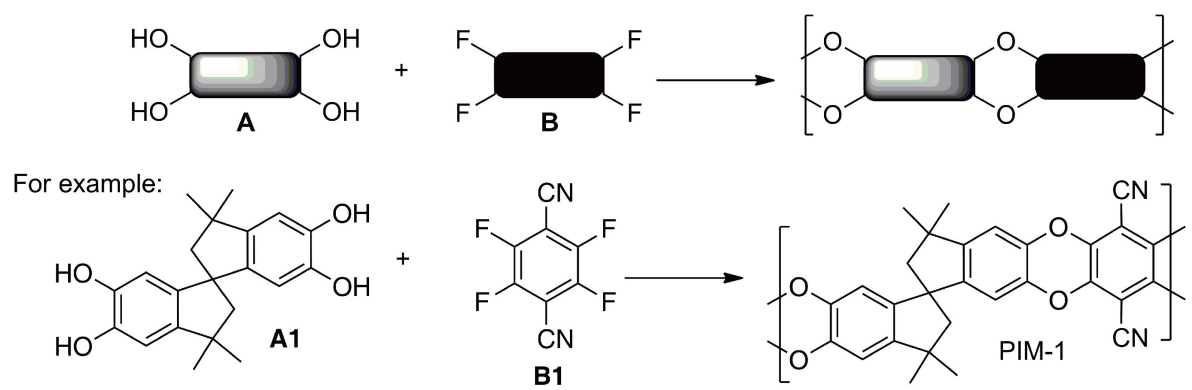

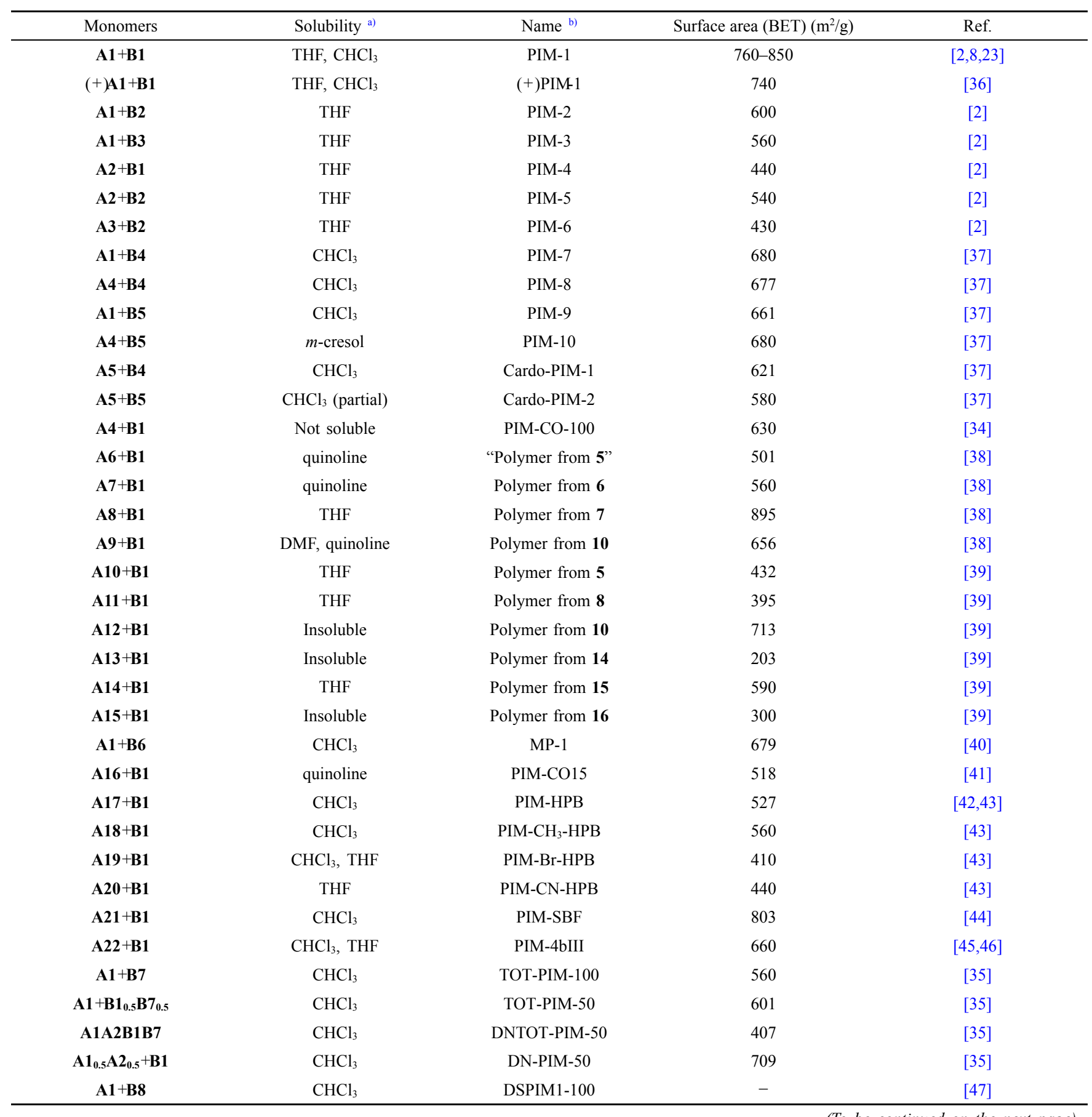




\begin{tabular}{|c|c|c|c|c|}
\hline Monomers & Solubility a) & Name ${ }^{b)}$ & Surface area $(\mathrm{BET})\left(\mathrm{m}^{2} / \mathrm{g}\right)$ & Ref. \\
\hline A1+B9 & $\mathrm{CHCl}_{3}$ & DSPIM2-100 & - & [47] \\
\hline A1+B10 & $\mathrm{CHCl}_{3}$ & DSPIM3-100 & - & [47] \\
\hline A1+B11 & $\mathrm{CHCl}_{3}$ & PSTFPIM1 & - & [48] \\
\hline $\mathbf{A 1}+\mathbf{B} 12$ & $\mathrm{CHCl}_{3}$ & - & - & [49] \\
\hline A1+B13 & $\mathrm{CHCl}_{3}$ & PIM-R1 & 702 & {$[50]$} \\
\hline A1+B14 & $\mathrm{CHCl}_{3}$ & PIM-R2 & 595 & [50] \\
\hline A1+B15 & $\mathrm{CHCl}_{3}$ & PIM-R3 & 628 & {$[50]$} \\
\hline $\mathrm{A} 1+\mathrm{B} 16$ & $\mathrm{CHCl}_{3}$ & PIM-R4 & 889 & {$[50]$} \\
\hline $\mathbf{A 1}+\mathbf{B} 17$ & $\mathrm{CHCl}_{3}$ & PIM-R5 & 636 & [50] \\
\hline A1+B18 & $\mathrm{CHCl}_{3}$ & PIM-R6 & 714 & {$[50]$} \\
\hline A1+B19 & $\mathrm{CHCl}_{3}$ & PIM-R7 & 680 & {$[50]$} \\
\hline A4+B20 & $\mathrm{CHCl}_{3}$ & PIM-A1 & - & [51] \\
\hline $\mathbf{A} 23+\mathbf{B} 1$ & $\mathrm{CHCl}_{3}$ & Polymer 4 & - & [29] \\
\hline A24+B1 & $\mathrm{CHCl}_{3}$ & PIM-c1 & 818 & {$[52]$} \\
\hline AB1 & $\mathrm{CHCl}_{3}$ & - & 523 & [31] \\
\hline AB2 & $\mathrm{CHCl}_{3}$ & TPIM-1 & 862 & [32] \\
\hline AB3 & $\mathrm{CHCl}_{3}$ & TPIM-2 & 612 & [32] \\
\hline AB4 & $\mathrm{CHCl}_{3}$ & PIM-1 & - & [30] \\
\hline
\end{tabular}

a) Insoluble: it is thought that this molecule is cross-linked due to an additional Aldol reaction, which takes place during polymerization; b) as denoted in reference.

omers of modest molecular mass are formed. The optimal concentration appears to be around $3 \mathrm{mmol}$ of each monomer per $10-15 \mathrm{~mL}$ DMF. Alternatively, the very rapid "high temperature method", described by Guiver et al. $[23,24]$ involves the high-speed stirring of the monomer mixture in dimethyl acetamide at $155^{\circ} \mathrm{C}$ with the addition of toluene to enable the continuation of stirring. A recent report suggests dimethylsulfoxide as a non-toxic and more environmentally benign solvent for PIM synthesis with $120^{\circ} \mathrm{C}$ suggested as the optimum reaction temperature [25]. These polymerisation methods all provide PIM-1 with sufficiently high average molecular mass to provide mechanically robust solvent cast films (typically $M_{\mathrm{n}}>30 \times 10^{3} \mathrm{~g} / \mathrm{mol}$ and $M_{\mathrm{w}}>100 \times 10^{3} \mathrm{~g} / \mathrm{mol}$ ) and have been adapted for the synthesis of many PIMs using a wide range of biscatechol (A1-A24) and halide-based monomers (B1-B20) (Table 1).

A modified "high temperature" method of continuous production of PIM-1 using a flow reactor has been patented, although the average molecular mass of the resulting polymer was modest $\left(M_{\mathrm{n}} \approx 6 \times 10^{3} \mathrm{~g} / \mathrm{mol}\right)$ [26]. An intriguing report of a very rapid mechanochemical synthesis of PIM-1 requires further investigation due to the extraordinarily high molecular mass of the product, as measured by gel permeation chromatography $\left(M_{\mathrm{n}}>300 \times 10^{3} \mathrm{~g} / \mathrm{mol}\right)$, which suggests the formation of cross-linked nanogels [27]. The film-forming properties of this material were not reported.

Alternative precursors for making PIM-1 have been used. For example, the tetra-silyl ether of biscatechol A1, gives PIM-1 via a fluoride-mediated reaction but the synthesis of the precursor appears to be an unnecessary additional synthetic step [28,29]. PIM-1 has also been prepared using an AB monomer (AB4, Scheme 1) which avoids potential complications arising from non-equivalent stoichiometry during the conventional AA-BB monomer mixture but also involves an additional synthetic step [30]. However, the use of $A B$ monomers has been successfully used for making triptycenebased PIMs (AB1-3) [31,32]. An elegant method of preparing PIMs with alternating biscatechol monomeric units involves the synthesis of a tetrafluoro monomer (B20) via the reaction between a biscatechol $\mathbf{A 1}$ with an excess of B1.

Despite the remarkable solubility of many PIMs some combinations of monomers result in insoluble material [33]. One example of such an insoluble PIM is that formed from monomers A4 and B1 [34]. A partial solution to this problem can be the synthesis of copolymers using the monomer that results in an insoluble polymer in combination with a monomer that results in a PIM with good solubility (e.g. A1) $[34,35]$.

\section{PIM polymerisation using Tröger's base for- mation}

Tröger's base (TB), more formally named as 2,8-dimethyl$6 H, 12 H-5,11$-methanodibenzo[b,f][1,5]diazocine, is readily formed by an electrophilic aromatic substitution reaction between an aromatic amine and formaldehyde or a formaldehyde proxy (e.g. dimethoxy methane). The reaction is remarkable in that six new covalent bonds are formed in a single 
high-yielding step. TB has proven to be an excellent linking group for PIM synthesis due to its bridged bicyclic structure that provides both high rigidity and a site of contortion. Despite its long history [53,54] and proven efficiency [55], the use of TB formation in PIM synthesis was the first report of a successful polymerization using this reaction [56,57]. In general, TB polymerisations are performed readily by simply mixing a suitable aromatic diamine monomer and five molar excess of dimethoxymethane in trifluoroacetic acid at
$0{ }^{\circ} \mathrm{C}$ and leaving under ambient conditions until the solution becomes viscous (Table 2) [58]. The need for only one type of aromatic monomer is an attractive feature of this step-growth polymerisation. For aromatic diamine monomers that possess more sites activated towards aromatic electrophilic substitution than the two required for TB polymerisation, gel formation due to cross-linking can be problematic. However, gel-formation can be avoided by using monomers within which methyl groups block these sites (e.g. C8, Scheme 2).

Table 2 PIMs prepared using Tröger's base polymerisation

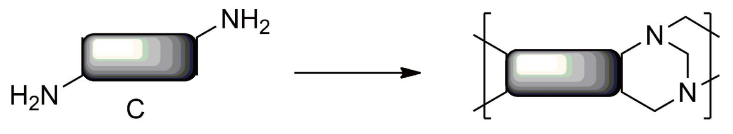

PIM-TB

For example:

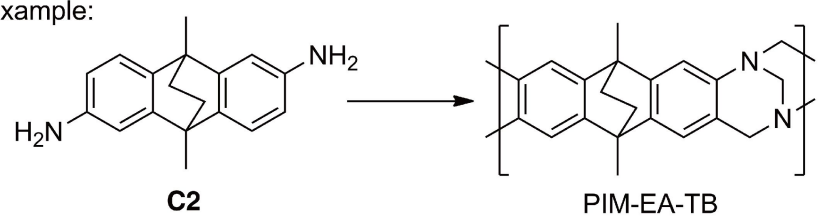

\begin{tabular}{|c|c|c|c|c|}
\hline Monomer & Solubility & Name & Surface area $(\mathrm{BET})\left(\mathrm{m}^{2} / \mathrm{g}\right)$ & Ref. \\
\hline C1 & $\mathrm{CHCl}_{3}$ & PIM-SBI-TB & 745 & {$[57,58]$} \\
\hline $\mathbf{C 2}$ & $\mathrm{CHCl}_{3}$ & PIM-EA-TB & 1028 & {$[57,58]$} \\
\hline $\mathbf{C 3}$ & $\mathrm{CHCl}_{3}$ & PIM-Trip-TB & 899 & {$[59,58]$} \\
\hline $\mathrm{C} 4$ & $\mathrm{CHCl}_{3}$ & PIM-SBF-TB & 566 & {$[58,58]$} \\
\hline C5 & $\mathrm{CHCl}_{3}$ & Polymer 5 & 536 & {$[58]$} \\
\hline C6 & $\mathrm{CHCl}_{3}$ & Polymer 8 & 504 & {$[58]$} \\
\hline C8 & $\mathrm{CHCl}_{3}$ & TB-Ad-Me & 605 & {$[60]$} \\
\hline C9 & $\mathrm{CHCl}_{3}$ & PI-TB-1 & 544 & {$[61]$} \\
\hline $\mathrm{C10}$ & $\mathrm{CHCl}_{3}$ & PI-TB-2 & 270 & [61] \\
\hline C11 & $\mathrm{CHCl}_{3}$ & PIM-BTrip-TB & 870 & {$[62]$} \\
\hline
\end{tabular}<smiles>CC1(C)CC2(CC(C)(C)C3(CC(C)(C)c4cc(N)ccc4C3(C)C)c3ccc(N)cc32)c2cc(N)ccc21</smiles>

C1

C2

C3<smiles>Cc1c(N)cccc1N</smiles><smiles>Cc1cc(N)c([Ge])cc1N</smiles><smiles>Cc1cc(C2(c3ccc(N)c(C)c3)C3CC4CC(C3)CC2C4)ccc1N</smiles>

C8<smiles>COc1cc(N2C(=O)c3ccc(C(C)(c4ccc5c(c4)C(=O)N(c4cc(C)c(N)cc4C)C5=O)C(F)(F)F)cc3C2=O)c(C)cc1N</smiles><smiles>COc1cc(N2C(=O)c3ccc(C(=O)c4ccc5c(c4)C(=O)N(c4cc(C)c(C)cc4C)C5=O)cc3C2=O)c(C)cc1N</smiles><smiles>Nc1ccc2c(c1)C1c3cc(N)ccc3C2c2cc3ccccc3cc21</smiles>

Scheme 2 Structures of monomers C1-C11. 
With the exception of monomers $\mathbf{C 6}$ and $\mathbf{C 7}$ (Scheme 2), TB polymerisation provides polymers of good film-forming quality by casting from chloroform.

\section{PIM polymerisation from imide formation: PIM-polyimides}

Polyimides constitute one of the most important classes of polymer for commercial applications and are prepared via the efficient formation of imide linkages between diamine and dianhydride monomers. PIMs based on polyimide formation (PIM-PIs) can be obtained from monomers (D1-D9, and E1-E23, Scheme 3) that are rigid with at least one of the monomers providing a site of contortion (Table 3) [63,64]. In addition, to obtain PIM-PIs with a high degree of intrinsic microporosity, it is important to restrict rotation about the $\mathrm{C}-\mathrm{N}$ bond of the imide linkage by choosing diamine monomers with two bulky substituents adjacent to both amine groups (Figure 1).

\section{Post synthetic modification of PIMs}

It is also possible to modify the structure of PIMs by post-synthesis reactions, which have mainly focused on performing chemistry on the nitrile group of PIM-1 (Figure 2) [83-90]. Simple hydrolysis of the $\mathrm{CN}$ groups was reported to provide carboxylic acids [83], although a later report suggests that simple hydrolysis under basic conditions mainly results in amide functionality [86]. Similarly, reaction of the nitrile group with $\mathrm{P}_{2} \mathrm{~S}_{5}$ gives thioamides [85], hydroxylamine gives amidoximes [84], borane gives benzyl amine [89], amines give amides [90], and the reaction of sodium nitride gives tetrazole functionality [87]. Generally, such modifications result in a reduction in intrinsic microporosity, presumably due to the additional inter-chain cohesive interactions from hydrogen bonding. Attempted post-synthesis modifications to the biscatechol monomeric units such as sulfonation have been less successful due to polymer degradation, insolubility and embrittlement [91]. Structural modifications from thermal $[92,93]$, and photooxidative $[70,94,95]$ processes generally reduce intrinsic microposity, as shown by a reduction in gas permeability but can greatly enhance selectivity for one gas over another. An interesting approach to polymers for membrane applications has been to combine the concept of intrinsic microporosity with that of the so-called thermally rearranged (TR) polymers. For example, PIM-PIs with reactive -OH substituents next to the imide liking group form benzoxazole units on heating $[65,75,96-98]$. These PIMs, like all TR
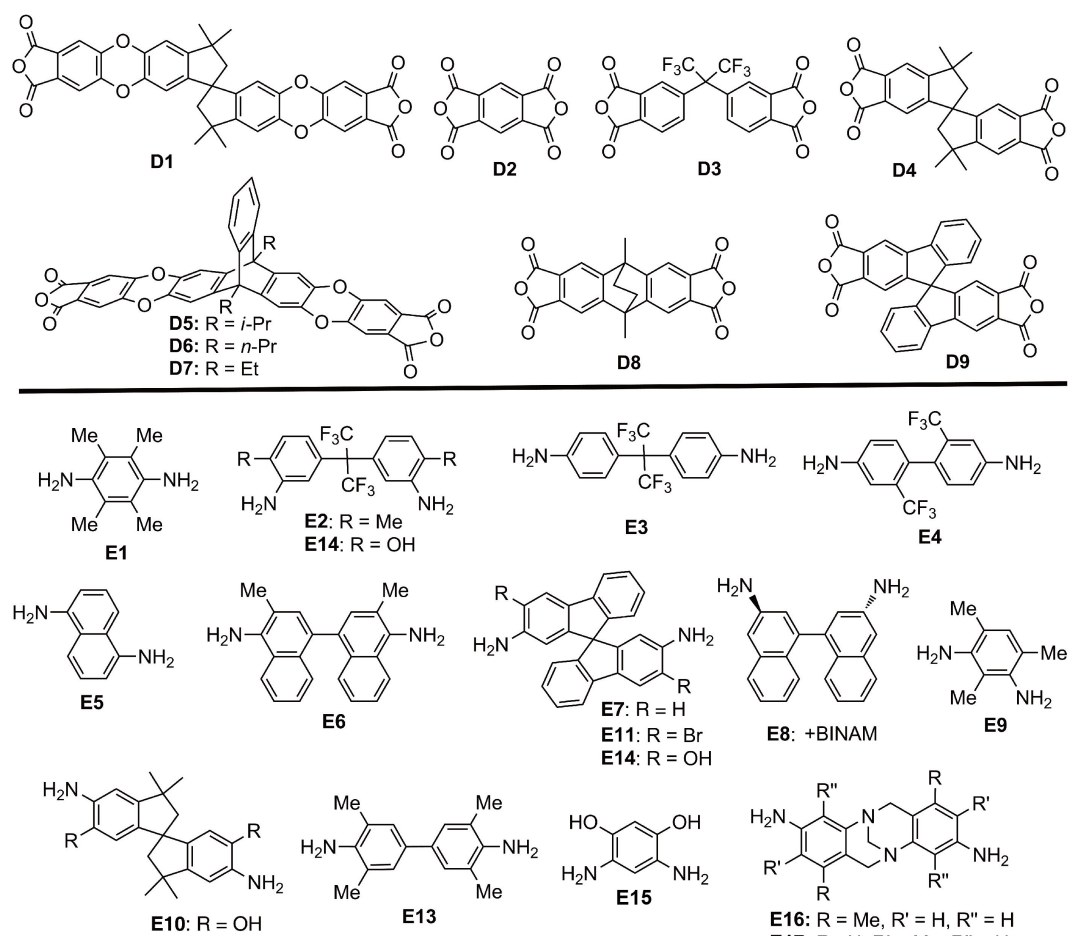

E14: $\mathrm{R}=\mathrm{OH}$

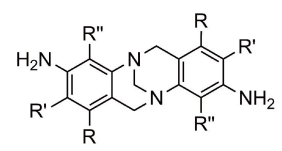

E16: $R=M e, R^{\prime}=H, R^{\prime \prime}=H$

118: $R=M e, R^{\prime}=M e R^{\prime \prime}$

E12: $R=H$

E13

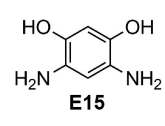

E18: $R=M e, R^{\prime}=M e, R^{\prime \prime}=B r$
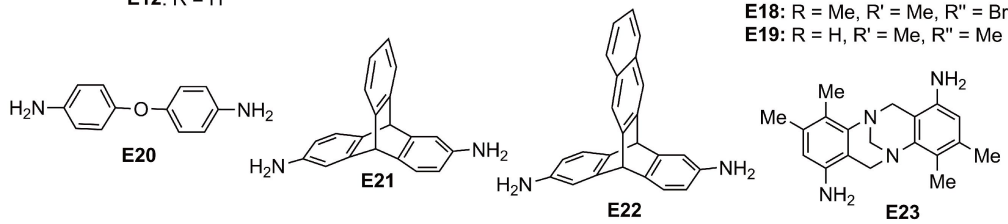

Scheme 3 Structures of monomers D1-D9 and E1-E23. 
Table 3 PIMs prepared using polyimide formation

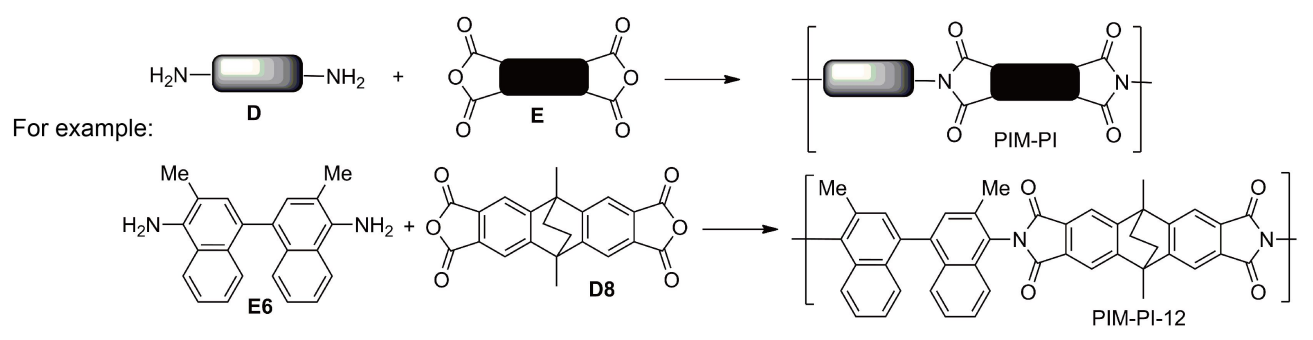

\begin{tabular}{|c|c|c|c|c|}
\hline Monomers & Solubility & Name a) & Surface area $(\mathrm{BET})\left(\mathrm{m}^{2} / \mathrm{g}\right)$ & Ref. \\
\hline D1+E1 & $\mathrm{CHCl}_{3}$ & PIM-PI-1 & 680 & {$[63,64]$} \\
\hline D1 +E2 & $\mathrm{CHCl}_{3}$ & PIM-PI-2 & 500 & [64] \\
\hline $\mathbf{D 1}+\mathbf{E 3}$ & $\mathrm{CHCl}_{3}$ & PIM-PI-3 & 471 & {$[63,64]$} \\
\hline D1 +E4 & $\mathrm{CHCl}_{3}$ & PIM-PI-4 & 486 & {$[64]$} \\
\hline D1 +E5 & $\mathrm{CHCl}_{3}$ & PIM-PI-7 & 485 & {$[64]$} \\
\hline D1+E6 & $\mathrm{CHCl}_{3}$ & PIM-PI-8 & 683 & {$[63,64]$} \\
\hline D1 + E14 & THF & SPDA-HSBF & 400 & {$[65]$} \\
\hline D2 +E7 & $\mathrm{CHCl}_{3}$ & $\mathrm{P} 4$ & 551 & {$[66]$} \\
\hline $\mathbf{D 2}+\mathbf{E 8}(+)$ & $\mathrm{CHCl}_{3}$ & $(+)$ BINAM-PMDA & 500 & {$[67]$} \\
\hline D3+E1 & THF & 6FDA-m4 & - & [68] \\
\hline D4+E9 & THF & 6FDA-m3 & - & {$[68]$} \\
\hline D2 + E10 & THF & PIM-6FDA-OH & 225 & [69] \\
\hline D3+E10 & THF & PIM-PMDA-OH & 190 & [69] \\
\hline $\mathbf{D 3}+\mathbf{E} 7$ & $\mathrm{CHCl}_{3}, \mathrm{THF}$ & 6FDA-SBF & 240 & {$[70]$} \\
\hline D2+E7 & $\mathrm{CHCl}_{3}, \mathrm{THF}$ & PMDA-SBF & 320 & {$[70]$} \\
\hline $\mathbf{D 1}+\mathbf{E} 7$ & $\mathrm{CHCl}_{3}, \mathrm{THF}$ & SPDA-SBF & 460 & {$[70]$} \\
\hline D3+E11 & $\mathrm{CHCl}_{3}$, THF & 6FDA-BSBF & 440 & {$[70]$} \\
\hline D2+E11 & $\mathrm{CHCl}_{3}, \mathrm{THF}$ & PMDA-BSBF & 450 & {$[70]$} \\
\hline D2+E11 & $\mathrm{CHCl}_{3}, \mathrm{THF}$ & SPDA-BSBF & 510 & {$[70]$} \\
\hline D4+E1 & $\mathrm{CHCl}_{3}$ & PIM-PI-9 & 700 & {$[71]$} \\
\hline D4+E6 & $\mathrm{CHCl}_{3}$ & PIM-PI-10 & 700 & [71] \\
\hline D4+E12 & $\mathrm{CHCl}_{3}$ & PIM-PI-11 & 200 & [71] \\
\hline D5+E1 & $\mathrm{CHCl}_{3}$ & KAUST-PI-1 & 752 & {$[72,73]$} \\
\hline D5+E12 & $\mathrm{CHCl}_{3}$ & KAUST-PI-2 & 737 & {$[72,73]$} \\
\hline D5+E9 & $\mathrm{CHCl}_{3}$ & KAUST-PI-3 & 760 & [73] \\
\hline D5 + E20 & $\mathrm{CHCl}_{3}$ & KAUST-PI-4 & 420 & [73] \\
\hline D5 + E3 & $\mathrm{CHCl}_{3}$ & KAUST-PI-5 & 650 & {$[73]$} \\
\hline D5 + E2 & $\mathrm{CHCl}_{3}$ & KAUST-PI-6 & 500 & {$[73]$} \\
\hline D5+E6 & $\mathrm{CHCl}_{3}$ & KAUST-PI-7 & 840 & [73] \\
\hline D6 + E1 & $\mathrm{CHCl}_{3}$ & KAUST-PI-1' & 610 & [73] \\
\hline D6 + E3 & $\mathrm{CHCl}_{3}$ & KAUST-PI-5' & 430 & [73] \\
\hline D7+E5 & $\mathrm{CHCl}_{3}$ & KAUST-PI-5" & 430 & [73] \\
\hline D8+E6 & THF & PIM-PI-12 & 699 & {$[74]$} \\
\hline D1 +E14 & THF & PIM-PI-OH-1 & 360 & {$[75]$} \\
\hline D4+E14 & DMAc & PIM-PI-OH-2 & - & {$[75]$} \\
\hline D1+E15 & THF(p), DMA & PIM-PI-OH-3 & 430 & {$[75]$} \\
\hline D1+E16 & $\mathrm{CHCl}_{3}$ & TBDAI-SBI-PI & 560 & {$[76]$} \\
\hline D1+E17 & $\mathrm{CHCl}_{3}$ & TBDA2-SBI-PI & 615 & {$[76]$} \\
\hline $\mathbf{D 3}+\mathbf{E} 17$ & $\mathrm{CHCl}_{3}$ & TBDA2-6FDA-PI & 320 & {$[77]$} \\
\hline
\end{tabular}

(To be continued on the next page) 


\begin{tabular}{|c|c|c|c|c|}
\hline Monomers & Solubility & Name ${ }^{\text {a) }}$ & Surface area $(\mathrm{BET})\left(\mathrm{m}^{2} / \mathrm{g}\right)$ & Ref. \\
\hline D3+E21 & $\mathrm{CHCl}_{3}$ & 6FDA-DAT1 & 320 & [78] \\
\hline D3+E22 & $\mathrm{CHCl}_{3}$ & 6FDA-DAT2 & 450 & [78] \\
\hline D9+E6 & $\mathrm{CHCl}_{3}$ & SBFDA-DMN & 686 & [79] \\
\hline D5+E2 & $\mathrm{CHCl}_{3}$ & TBDA-ATAF & - & [80] \\
\hline D5+E14 & THF & TPDA-APAF & - & [80] \\
\hline D3+E18 & $\mathrm{CHCl}_{3}$, THF & PIM-PI-TB-1 & 440 & [81] \\
\hline D3+E23 & $\mathrm{CHCl}_{3}$, THF & PIM-PI-TB-2 & 580 & [81] \\
\hline D2+E19 & $\mathrm{CHCl}_{3}$, & 4MTBDA-PMDA & 650 & [82] \\
\hline D3+E19 & $\mathrm{CHCl}_{3}$, & 4MTBDA-6FDA & 584 & [82] \\
\hline D4+E19 & $\mathrm{CHCl}_{3}$, & 4MTBDA-SBIDA & 733 & [82] \\
\hline D9+E19 & $\mathrm{CHCl}_{3}$, & 4MTBDA-SBFDA & 739 & [82] \\
\hline
\end{tabular}

a) As denoted in reference.
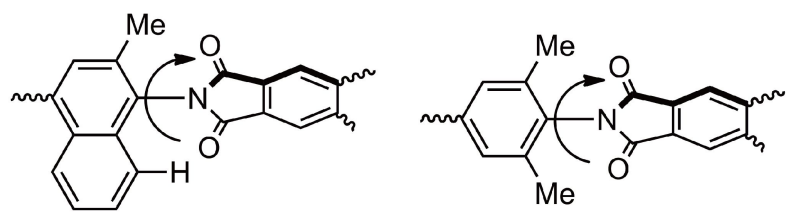

Figure 1 Restricted rotation around sterically crowded imide bonds.

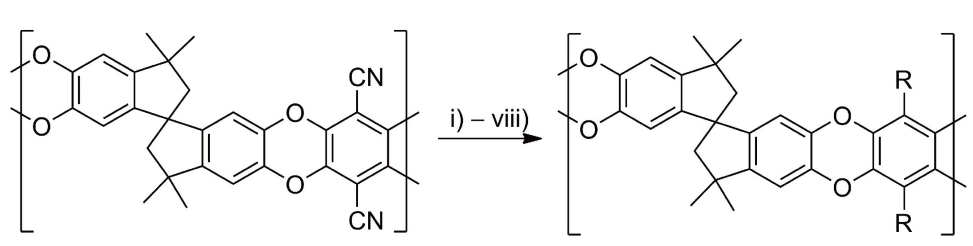

$\begin{array}{ll}\text { i) } \mathrm{R}=-\mathrm{CO}_{2} \mathrm{H} & \text { iv) } \mathrm{R}=-\mathrm{CONH}_{2}\end{array}$

ii) $\mathrm{R}=-\overbrace{\mathrm{NHOH}}^{\mathrm{NH}}$

v); vi) $R=\overbrace{H^{-}-N}^{N-N}$

iii) $\mathrm{R}=-\mathrm{CSNH}_{2} \quad$ vii) $\mathrm{R}=-\mathrm{CH}_{2} \mathrm{NH}_{2}$

viii) $\mathrm{R}=-\mathrm{CONHCH}_{2} \mathrm{CH}_{2} \mathrm{NHCH}_{2} \mathrm{CH}_{2} \mathrm{OH}$

Figure 2 Post-synthetic modification of PIM-1. Reactions and conditions: i) $\mathrm{NaOH}$ (aq), reflux; acidic work-up [83]; ii) $\mathrm{NH}_{2} \mathrm{OH}$, THF, reflux [84]; iii) $\mathrm{P}_{2} \mathrm{~S}_{5}$, $\mathrm{NaSO}_{3}$, dioxane, ethanol, reflux [85]; iv) $\mathrm{NaOH}$ (aq), reflux, acidic work-up [86]; v) $\mathrm{NaN}_{3}, \mathrm{ZnCl}_{2}$ [87,88]; vi) $\mathrm{NaN}_{3}, \mathrm{ZnCl}_{2}, \mathrm{~K}_{2} \mathrm{CO}_{3}$, MeI [88]; vii) borane-THF, THF, reflux [89]; viii) ethanolamine, reflux [90].

polymers become insoluble on thermal processing. Post-synthetic sgcross-linking using a variety of reactions such as those of azides [99], nitrenes [100], decarboxylation of hydrolysed PIM-1 [101], has also been investigated due to its importance for membrane stability. Post-synthesis modification of PIM-TB polymers to give positively charged polyelectrolytes, suitable for highly efficient anion transport, has been achieved by quaternisation of the tertiary amine functionality of the TB unit [10].

\section{Conclusions}

Described above is the accumulation of over 12 years work on the synthesis of PIMs. The simple design concept of constructing highly rigid, conformationally locked, and contorted polymer chains is often challenging to achieve with conventional polymerisations. Nevertheless, three distinct types of reactions based on the formation of dibenzodioxin, Tröger's base and imide linkages reliably provide PIMs of sufficient molecular mass to form robust self-standing films by simple solution casting. It is anticipated that the many potential applications of PIMs, as solution processable microporous materials, will provide increasing impetus for the further design and synthesis of PIMs using these three proven synthetic methodologies and also the development of new PIM-forming polymerisation reactions.

Acknowledgments I thank the members of my research group, both past and present, and my collaborators on PIM research for their invaluable input.

Conflict of interest The author declares that they have no conflict of interest.

1 Slater AG, Cooper AI. Science, 2015, 348: aaa8075

2 Budd PM, Ghanem BS, Makhseed S, McKeown NB, Msayib KJ, Tattershall CE. Chem Commun, 2004, 230-231

3 McKeown NB, Budd PM. Macromolecules, 2010, 43: 5163-5176

4 McKeown NB, Budd PM. Chem Soc Rev, 2006, 35: 675-683

5 McKeown NB. ISRN Mater Sci, 2012, 2012: 1-16 
6 Wang Y, McKeown NB, Msayib KJ, Turnbull GA, Samuel IDW. Sensors, 2011, 11: 2478-2487

7 Rakow NA, Wendland MS, Trend JE, Poirier RJ, Paolucci DM, Maki SP, Lyons CS, Swierczek MJ. Langmuir, 2010, 26: 3767-3770

8 Budd PM, Elabas ES, Ghanem BS, Makhseed S, McKeown NB, Msayib KJ, Tattershall CE, Wang D. Adv Mater, 2004, 16: 456-459

9 Budd P, Mckeown N, Ghanem B, Msayib K, Fritsch D, Starannikova L, Belov N, Sanfirova O, Yampolskii Y, Shantarovich V. J Membrane Sci, 2008, 325: 851-860

10 Yang Z, Guo R, Malpass-Evans R, Carta M, McKeown NB, Guiver MD, Wu L, Xu T. Angew Chem Int Ed, 2016, 55: 11499-11502

11 Madrid E, Rong Y, Carta M, McKeown NB, Malpass-Evans R, Attard GA, Clarke TJ, Taylor SH, Long YT, Marken F. Angew Chem Int Ed, 2014, 53: 10751-10754

12 Cheng G, Hasell T, Trewin A, Adams DJ, Cooper AI. Angew Chem Int Ed, 2012, 51: 12727-12731

13 Cheng G, Bonillo B, Sprick RS, Adams DJ, Hasell T, Cooper AI. Adv Funct Mater, 2014, 24: 5219-5224

14 Zhu X, Tian C, Mahurin SM, Chai SH, Wang C, Brown S, Veith GM, Luo H, Liu H, Dai S. J Am Chem Soc, 2012, 134: 10478-10484

15 Liu S, Jin Z, Teo YC, Xia Y. J Am Chem Soc, 2014, 136: 17434-17437

16 Ranganathan K, Anbanandam P. Polym Chem, 2015, 6: 4560-4564

17 Jimenez-Solomon MF, Song Q, Jelfs KE, Munoz-Ibanez M, Livingston AG. Nat Mater, 2016, 15: 760-767

18 Budd PM, Ghanem B, Msayib K, McKeown NB, Tattershall C. $J$ Mater Chem, 2003, 13: 2721-2726

19 McKeown NB, Makhseed S, Budd PM. Chem Commun, 2002, 2780-2781

20 McKeown NB, Hanif S, Msayib K, Tattershall CE, Budd PM. Chem Commun, 2002, 2782-2783

21 McKeown NB, Budd PM, Ghanem B, Msayib K. Microporous polymer material. International Patent, PCT WO 2005/012397, 2005

22 Eastmond GC, Paprotny J, Steiner A, Swanson L. New J Chem, 2001, 25: $379-384$

23 Du N, Song J, Robertson GP, Pinnau I, Guiver MD. Macromol Rapid Commun, 2008, 29: 783-788

24 Song J, Du N, Dai Y, Robertson GP, Guiver MD, Thomas S, Pinnau I. Macromolecules, 2008, 41: 7411-7417

25 Ponomarev II, Blagodatskikh IV, Muranov AV, Volkova YA, Razorenov DY, Ponomarev II, Skupov KM. Mendeleev Commun, 2016, 26: $362-364$

26 Fritsch D. Production of polymers with inherent microporosity. US patent, 2010/0130634, 2010

27 Zhang P, Jiang X, Wan S, Dai S. J Mater Chem A, 2015, 3: 6739-6741

28 Kricheldorf HR, Fritsch D, Vakhtangishvili L, Schwarz G. Macromol Chem Phys, 2005, 206: 2239-2247

29 Zhang J, Jin J, Cooney R, Zhang S. Polymer, 2015, 76: 168-172

30 Zhang J, Jin J, Cooney R, Zhang S. Polymer, 2015, 57: 45-50

31 Ghanem BS. Polym Chem, 2012, 3: 96-98

32 Ghanem BS, Swaidan R, Ma X, Litwiller E, Pinnau I. Adv Mater, 2014, 26: 6696-6700

33 Vile J, Carta M, Bezzu CG, Kariuki BM, McKeown NB. Polymer, 2014, 55: 326-329

34 Emmler T, Heinrich K, Fritsch D, Budd PM, Chaukura N, Ehlers D, Rätzke K, Faupel F. Macromolecules, 2010, 43: 6075-6084

35 Du N, Robertson GP, Pinnau I, Guiver MD. Macromolecules, 2010, 43: $8580-8587$

36 Weng X, Baez JE, Khiterer M, Hoe MY, Bao Z, Shea KJ. Angew Chem Int $E d, 2015,54: 11214-11218$
37 Ghanem BS, McKeown NB, Budd PM, Fritsch D. Macromolecules, 2008, 41: 1640-1646

38 Carta M, Msayib KJ, Budd PM, McKeown NB. Org Lett, 2008, 10: 2641-2643

39 Carta M, Msayib KJ, McKeown NB. Tetrahedron Lett, 2009, 50: 5954-5957

40 Makhseed S, Samuel J, Bumajdad A, Hassan M. J Appl Polym Sci, 2008, 109: 2591-2597

41 Fritsch D, Bengtson G, Carta M, McKeown NB. Macromol Chem Phys, 2011, 212: 1137-1146

42 Short R, Carta M, Bezzu CG, Fritsch D, Kariuki BM, McKeown NB. Chem Commun, 2011, 47: 6822-6824

43 Carta M, Bernardo P, Clarizia G, Jansen JC, McKeown NB. Macromolecules, 2014, 47: 8320-8327

44 Bezzu CG, Carta M, Tonkins A, Jansen JC, Bernardo P, Bazzarelli F, McKeown NB. Adv Mater, 2012, 24: 5930-5933

45 Khan MM, Bengtson G, Neumann S, Rahman MM, Abetz V, Filiz V. RSC Adv, 2014, 4: 32148-32160

46 Khan MM, Filiz V, Emmler T, Abetz V, Koschine T, Rätzke K, Faupel F, Egger W, Ravelli L. Membranes, 2015, 5: 214-227

47 Du N, Robertson GP, Pinnau I, Guiver MD. Macromolecules, 2009, 42: 6023-6030

48 Du N, Robertson GP, Song J, Pinnau I, Thomas S, Guiver MD. Macromolecules, 2008, 41: 9656-9662

49 Kricheldorf HR, Fritsch D, Vakhtangishvili L, Lomadze N, Schwarz G. Macromolecules, 2006, 39: 4990-4998

50 Makhseed S, Ibrahim F, Samuel J. Polymer, 2012, 53: 2964-2972

51 Zhang J, Jin J, Cooney R, Fu Q, Qiao GG, Thomas S, Merkel TC. Polym Chem, 2015, 6: 5003-5008

52 Zhang J, Kang H, Martin J, Zhang S, Thomas S, Merkel TC, Jin J. Chem Commun, 2016, 52: 6553-6556

53 Tröger J. J Prakt Chem, 1887, 36: 227

54 Spielman MA. J Am Chem Soc, 1935, 57: 583-585

55 Didier D, Tylleman B, Lambert N, Vande Velde CML, Blockhuys F, Collas A, Sergeyev S. Tetrahedron, 2008, 64: 6252-6262

56 Carta M, Croad M, McKeown NB. Polymerisation method. International Patent, WO 2012/035327 A1, 2010

57 Carta M, Malpass-Evans R, Croad M, Rogan Y, Jansen JC, Bernardo P, Bazzarelli F, McKeown NB. Science, 2013, 339: 303-307

58 Carta M, Malpass-Evans R, Croad M, Rogan Y, Lee M, Rose I, McKeown NB. Polym Chem, 2014, 5: 5267-5272

59 Carta M, Croad M, Malpass-Evans R, Jansen JC, Bernardo P, Clarizia G, Friess K, Lanč M, McKeown NB. Adv Mater, 2014, 26 : 3526-3531

60 Carta M, Croad M, Jansen JC, Bernardo P, Clarizia G, McKeown NB. Polym Chem, 2014, 5: 5255-5261

61 Zhuang Y, Seong JG, Do YS, Jo HJ, Cui Z, Lee J, Lee YM, Guiver MD. Macromolecules, 2014, 47: 3254-3262

62 Rose I, Carta M, Malpass-Evans R, Ferrari MC, Bernardo P, Clarizia G, Jansen JC, McKeown NB. ACS Macro Lett, 2015, 4: 912-915

63 Ghanem BS, McKeown NB, Budd PM, Selbie JD, Fritsch D. $A d v$ Mater, 2008, 20: 2766-2771

64 Ghanem BS, McKeown NB, Budd PM, Al-Harbi NM, Fritsch D, Heinrich K, Starannikova L, Tokarev A, Yampolskii Y. Macromolecules, 2009, 42: 7881-7888

65 Ma X, Salinas O, Litwiller E, Pinnau I. Polym Chem, 2014, 5: 6914-6922

66 Weber J, Su Q, Antonietti M, Thomas A. Macromol Rapid Commun, 2007, 28: 1871-1876

67 Ritter N, Senkovska I, Kaskel S, Weber J. Macromol Rapid Commun, 
2011, 32: 438-443

68 Tanaka K, Okano M, Toshino H, Kita H, Okamoto KI. J Polym Sci B Polym Phys, 1992, 30: 907-914

69 Ma X, Swaidan R, Belmabkhout Y, Zhu Y, Litwiller E, Jouiad M, Pinnau I, Han Y. Macromolecules, 2012, 45: 3841-3849

70 Ma X, Salinas O, Litwiller E, Pinnau I. Macromolecules, 2013, 46: 9618-9624

71 Rogan Y, Starannikova L, Ryzhikh V, Yampolskii Y, Bernardo P, Bazzarelli F, Jansen JC, McKeown NB. Polym Chem, 2013, 4: 3813-3820

72 Ghanem BS, Swaidan R, Litwiller E, Pinnau I. Adv Mater, 2014, 26 : 3688-3692

73 Swaidan R, Al-Saeedi M, Ghanem B, Litwiller E, Pinnau I. Macromolecules, 2014, 47: 5104-5114

74 Rogan Y, Malpass-Evans R, Carta M, Lee M, Jansen JC, Bernardo P, Clarizia G, Tocci E, Friess K, Lanč M, McKeown NB. J Mater Chem A, 2014, 2: 4874-4877

75 Shamsipur H, Dawood BA, Budd PM, Bernardo P, Clarizia G, Jansen JC. Macromolecules, 2014, 47: 5595-5606

76 Wang Z, Wang D, Jin J. Macromolecules, 2014, 47: 7477-7483

77 Wang Z, Wang D, Zhang F, Jin J. ACS Macro Lett, 2014, 3: 597-601

78 Alghunaimi F, Ghanem B, Alaslai N, Swaidan R, Litwiller E, Pinnau I. J Membrane Sci, 2015, 490: 321-327

79 Ma X, Ghanem B, Salines O, Litwiller E, Pinnau I. ACS Macro Lett, 2015, 4: 231-235

80 Swaidan R, Ghanem B, Litwiller E, Pinnau I. J Membrane Sci, 2015, 475: $571-581$

81 Ghanem B, Alaslai N, Miao X, Pinnau I. Polymer, 2016, 96: 13-19

82 Lee M, Bezzu CG, Carta M, Bernardo P, Clarizia G, Jansen JC, McKeown NB. Macromolecules, 2016, 49: 4147-4154

83 Du N, Robertson GP, Song J, Pinnau I, Guiver MD. Macromolecules, 2009, 42: 6038-6043

84 Patel HA, Yavuz CT. Chem Commun, 2012, 48: 9989-9991

85 Mason CR, Maynard-Atem L, Al-Harbi NM, Budd PM, Bernardo P, Bazzarelli F, Clarizia G, Jansen JC. Macromolecules, 2011, 44:
6471-6479

86 Satilmis B, Budd PM. RSC Adv, 2014, 4: 52189-52198

87 Du N, Park HB, Robertson GP, Dal-Cin MM, Visser T, Scoles L, Guiver MD. Nat Mater, 2011, 10: 372-375

88 Du N, Robertson GP, Dal-Cin MM, Scoles L, Guiver MD. Polymer, 2012, 53: 4367-4372

89 Mason CR, Maynard-Atem L, Heard KWJ, Satilmis B, Budd PM, Friess K, Lanč M, Bernardo P, Clarizia G, Jansen JC. Macromolecules, 2014, 47: 1021-1029

90 Satilmis B, Alnajrani MN, Budd PM. Macromolecules, 2015, 48: 5663-5669

91 Kim BG, Henkensmeier D, Kim HJ, Jang JH, Nam SW, Lim TH. Macromol Res, 2014, 22: 92-98

92 Li FY, Xiao Y, Chung TS, Kawi S. Macromolecules, 2012, 45: 1427-1437

93 Song Q, Cao S, Pritchard RH, Ghalei B, Al-Muhtaseb SA, Terentjev EM, Cheetham AK, Sivaniah E. Nat Commun, 2014, 5: 4813

94 Song Q, Cao S, Zavala-Rivera P, Ping Lu L, Li W, Ji Y, Al-Muhtaseb SA, Cheetham AK, Sivaniah E. Nat Commun, 2013, 4: 1918

95 Li FY, Xiao Y, Ong YK, Chung TS. Adv Energy Mater, 2012, 2: 1456-1466

96 Li S, Jo HJ, Han SH, Park CH, Kim S, Budd PM, Lee YM. J Membrane Sci, 2013, 434: 137-147

97 Swaidan RJ, Ma X, Litwiller E, Pinnau I. J Membrane Sci, 2015, 495: 235-241

98 Swaidan R, Ma X, Litwiller E, Pinnau I. J Membrane Sci, 2013, 447: 387-394

99 Du N, Cin MMD, Pinnau I, Nicalek A, Robertson GP, Guiver MD. Macromol Rapid Commun, 2011, 32: 631-636

100 Khan MM, Bengtson G, Shishatskiy S, Gacal BN, Mushfequr Rahman M, Neumann S, Filiz V, Abetz V. Eur Polymer J, 2013, 49: 4157-4166

101 Du N, Dal-Cin MM, Robertson GP, Guiver MD. Macromolecules, 2012, 45: 5134-5139 